Research Article

\title{
Distribution, Density, and Abundance of Parthenium Weed (Parthenium hysterophorus L.) at Kuala Muda, Malaysia
}

\author{
C. M. Maszura, S. M. R. Karim (iD, M. Z. Norhafizah, F. Kayat, and M. Arifullah \\ Faculty of Agro-Based Industry, Universiti Malaysia Kelantan, Jeli Campus, Kota Bharu, Malaysia \\ Correspondence should be addressed to S. M. R. Karim; rezaul@umk.edu.my
}

Received 2 January 2018; Accepted 29 April 2018; Published 25 June 2018

Academic Editor: Maria Serrano

Copyright (C) 2018 C. M. Maszura et al. This is an open access article distributed under the Creative Commons Attribution License, which permits unrestricted use, distribution, and reproduction in any medium, provided the original work is properly cited.

\begin{abstract}
Knowledge of distribution, density, and abundance of weed in a place is a prerequisite for its proper management. Parthenium hazard is a national agenda in Malaysia, and Kedah is the worst infested state in the country. Despite it, the distribution and abundance of the weed is not systematically documented. Periodical weed surveys were conducted at Kuala Muda, Kedah, during March and September 2015 to identify infested locations, to determine density, abundance, and severity of infestation, and to do mapping of weed distribution of the area. Geographic locations were recorded using a GPS. Weed density was measured following the list count quadrat method. The mapping of weed infestation was done by the ArcGIS software using data of GPS and weed density. Different letters were used to indicate the severity of infestation. Results indicated that in Kuala Muda, sixteen sites are infested having average weed density of 10.6 weeds $/ \mathrm{m}^{2}$. The highest density was noted at Kg. Kongsi $6\left(24.3\right.$ plants $\left./ \mathrm{m}^{2}\right)$. The relative density was highest at Semeling (27.25\%) followed by Kg. Kongsi 6 (23.14\%). The average severity of infestation was viewed as the medium. Parthenium abundance and relative density increased by $18.0 \%$ and $27 \%$, respectively, in the second survey conducted. The intervention of concerned authority to tackle the weed problem using integrated weed management approach is emphasized.
\end{abstract}

\section{Introduction}

The most obnoxious, allergenic, and environmental pollutant weed, Parthenium hysterophorus L. (locally called as Rumpai Miang Mexico) is an invasive alien species in Malaysia. The weed scientists of Universiti Malaysia Kelantan detected it for the first time at Batang Kali, Selangor, in 2013 [1-3]. At present, ten states of Malaysia are invaded by the weed, and the state Kedah is the worst infested area $[4,5]$. The weed has harmful impacts on crop production, livestock production, human and animal health, and biodiversity $[6,7]$. The weed spreads very fast through transport, agricultural implements, crop seeds, compost, and organic manures. It also spreads through flood water, wind pressure, and tyre-carried mud of vehicles [8]. It is essential to know the critical analytical characters such as density, frequency, and abundance of the species if we want to know its dominance in a community. Weed density measures the number of the species in a unit area, sometimes expressed as a percentage. Frequency is the number of times the species occur in the sampling unit, or it is the degree of dispersal of the species. The abundance of a species is the total number of the species present in the weed community and is a relative measure [9]. The severity of weed infestation usually regards the percentage of area covered by the species. The study of weed distribution, abundance, and severity over time are helpful in determining how a population changes over time in response to agronomic practices and agroclimatic conditions [5]. Therefore, it is essential to identify the parthenium infested locations, that is, the geographical range of the weed, its abundance, and severity of infestation in the study site. The primary objective of the study was to accurately identify the areas with parthenium populations and quantify their abundance and severity of infestation. It is intended that the scientists, land managers, and the inhabitants can foresee those areas, potentially subject to parthenium invasion, understand the biology of invasion process, and thereby develop the appropriate weed management plans. 


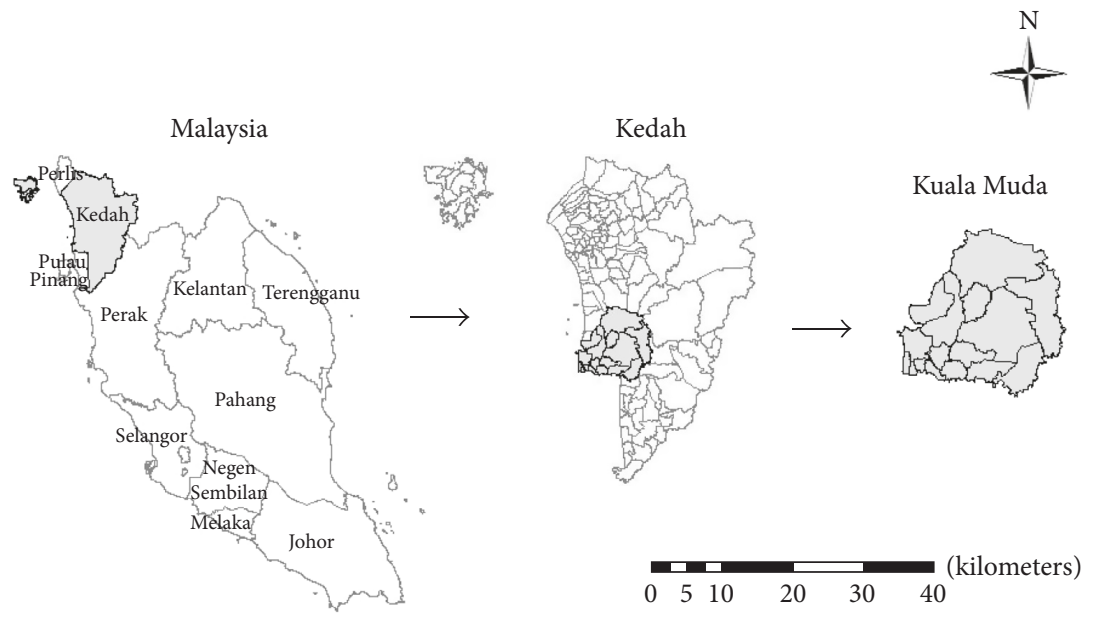

Figure 1: Map showing the study sites located at Kuala Muda, Kedah, Malaysia.

A regular weed monitoring is needed to control the weed sustainably. Weed monitoring involves repetitive surveys to track weed populations over time. The comparisons between different periodic surveys can help to elucidate the effect of new weed control technologies on weed species shift. Our preliminary investigation indicated that the weed is scattered in various areas of Batang Kali (Selangor) and Sungai Petani (Kedah), but detailed information was not documented from elsewhere $[2,5]$.

\section{Materials and Methods}

2.1. Location of Weed Survey. The weed survey was conducted at Kuala Muda $\left(05^{\circ} 38.770^{\prime} \mathrm{N}, 100^{\circ} 28.771^{\prime} \mathrm{E}\right)$ in Kedah, located in Peninsular Malaysia (Figure 1).

2.2. Procedure of Weed Survey. The field surveys were conducted throughout Kuala Muda subdistrict, Kedah, during March and September 2015. The observation was made alongside the highways and major roads of the study sites with an interval of 500 meters. The farmland, wasteland, and river bank around the survey spots were also considered in the survey following the list quadrat method $[9,10]$. The geographical coordinates were recorded using a GPS. When parthenium was observed at a density of at least one plant per $10 \mathrm{~m}^{2}$ area, it was considered as presence of the weed.

2.3. Determination of Relative Density and Abundance of Parthenium Weed. The weed density was measured by placing a quadrat $\left(1 \mathrm{~m}^{2}\right.$ size $)$ randomly on the survey spots following the list quadrat method [10]. Ten quadrats were placed at each site of the survey spots. Parthenium weed and other weed species within each quadrat were counted [11]. Parthenium weed density and frequency were calculated based on the formulae as applied by Tauseef et al. [12] and Nkoa et al. [5]. Whereas the relative density was determined using the equations of Yakubu et al. [13] and Knox et al. [14]. The abundance of parthenium weed invasion was determined based on the formula of Kilewa and Rashid [15]:

$$
\begin{aligned}
\text { density } & =\frac{\text { total number of parthenium weed in a quadrat }}{\text { total area of a quadrat }\left(1 \mathrm{~m}^{2}\right)} \times 100, \\
\text { frequency } & =\frac{\text { number of quadrats with parthenium weed }}{\text { total number of quadrats used in each spot }} \times 100, \\
\text { relative density } & =\frac{\text { total number of parthenium weed }}{\text { total number of all weed species }} \times 100, \\
\text { abundance } & =\frac{\text { total number of parthenium weed in all quadrats }}{\text { total number of quadrats in which parthenium weed occurred }} .
\end{aligned}
$$

2.4. Mapping the Distribution of Parthenium Infestation and the Percentage of Area Coverage (Severity Class). The information on parthenium distribution and severity of infestation marked on the base maps of Kedah following the technique of Cooksey and Sheley [16]. The mapping of parthenium weed distribution was done by measuring the percentage of area coverage completed by visual estimate within the quadrat according to Philippoff and Cox [17]. The 
TABLE 1: Classification of severity of parthenium infestation.

\begin{tabular}{lcc}
\hline Symbol used & Severity class & Percent coverage \\
\hline $\mathrm{T}$ & Trace/rare & Less than $1 \%$ \\
$\mathrm{~L}$ & Low/occasional plants & Between 1 and $5 \%$ \\
$\mathrm{M}$ & Moderate/scattered plants & Between 5 and $25 \%$ \\
$\mathrm{H}$ & High/fairly dense & Between 25 and $100 \%$ \\
\hline
\end{tabular}

Adopted from the U.S. Department of the Interior [18] and Cooksey and Sheley [16].

severity of infestation is categorized and presented in Table 1.

All the data of infested areas were transferred into a digital map using Geographic Information System (GIS) software, ArcGIS [16]. The distribution, density, and percentage of coverage by the parthenium weed were considered in mapping the weed infestation.

\section{Results and Discussion}

3.1. Location and Distribution of Parthenium Infestation. The survey results indicated that in Kuala Muda, Kedah, parthenium grew vigorously in 16 villages namely, Ladang Sungai Bongkok, Havard Golf Course area, Kg. Sungai Tok Rawang, Kg. Zainal Abidin, Kg. Semeling, Kg. Kongsi 6, Kg. Telok, Penghulu Him, Taman Kg. Raja, Batu Dua, Taman Songket Indah, Pokok Terap, Taman Nilam Sari, Taman Cahaya Baiduri, Teluk Wang Besar, and Kg. Banggol. Most of the villages have medium (M) level of infestation except the places like Batu Dua, Pokok Terap, Taman Nilam Sari, and $\mathrm{Kg}$. Banggol, where low (L) infestation was recorded, and at Teluk Wang Besar it was regarded as rare, especially during the first survey (Figure 2(a)). The difference in intensity of infestation is due to natural selection as no other extra influence has worked here to make difference.

However, during the second survey, all the villages had "medium" level of infestation signposted by "M," and $\mathrm{Kg}$. Semeling had a high level of infestation designated by " $\mathrm{H}$." It is mentioned here that the personnel from Department of Agriculture (DOA), Kedah, sprayed with glyphosate twice (trade name: Knockdown) between the surveys. Although the above-ground parts of the weed were destroyed, a vast number of seeds remained within the soil and emerged later with higher energy. That is why the infestation level was higher in the second survey (Figure 2(b)). Probably the weed seedbank of parthenium was encouraged after herbicide spraying above ground. Worku [19] stated that parthenium became the major weed in Ethiopia, India, and Australia within a short period, even after herbicide sprays. Therefore, continuous monitoring and control measures are needed for an extended period.

\subsubsection{Parthenium Preference according to Habitat. In Kuala} Muda, most of the infestations are noticed along roadsides, residential areas, wasteland, and crop farms (Figure 3). When parthenium is prevalent on roadsides, it is subject to quick spread through wind pressure of moving transports [20]. According to Ayele et al. [21], parthenium weed was introduced to Ethiopia in the year 1968 through cereals consignment. However, another form of introduction occurred to eastern Ethiopia in the year 1976 through weed seeds attached to the army transport at the time of EthioSomali war.

When parthenium grows in the wasteland, it usually remains undisturbed and leads the plant to produce a higher number of seeds. Parthenium growth in the residential area is dangerous to the inhabitants. The children who play with the weed are prone to be infected by parthenium showy white flowers which cause allergy. People may inhale the pollen from the parthenium flowers during breathing which might adversely affect their respiratory system. The weed surveyors noticed many parthenium plants in front of mosques and Hindu temples, which are also risky for the people who come for worships. The dominance of parthenium weed in crop farms may lead to its contamination with crop seeds which leads to its further spread. Upadhyay et al. [22] commented that parthenium weed commonly grows near the roadsides, in farms, and paddocks. Adnan et al. [11] also noted that most of the habitats infested by the parthenium weed are alongside road, the fields for crop cultivation, and wasteland rather than alongside water canal.

Presence of parthenium near cattle farm is risky for the cattle. If the cattle graze on the parthenium infested land, the animals might be infected with skin dermatitis due to close contact with the weed. When parthenium is abundant along the river bank or watercourses, the spread of the weed may occur due to the mixing of parthenium weed seeds with river water. All these information indicate the risks of the parthenium weed at Kuala Muda.

3.2. Density and Abundance of Parthenium Weed at Different Sites. The density, relative density, frequency, abundance, and other parameters of parthenium weed infestation at Kuala Muda, Kedah, are shown in Table 2.

3.2.1. Weed Density. The parthenium weed density at Kuala Muda, Kedah, significantly varied $(P<0.05)$ at different villages in both the surveys on March and September 2015. During the first survey, the highest density of parthenium weed was found at $\mathrm{Kg}$. Kongsi $6\left(18.8\right.$ weed $\left./ \mathrm{m}^{2}\right)$ followed by Taman Cahaya Baiduri (16.0 weed $\left./ \mathrm{m}^{2}\right)$, Kg. Penghulu Him $\left(15.8\right.$ weed $\left./ 1 \mathrm{~m}^{2}\right)$, and $\mathrm{Kg}$. Zainal Abidin $\left(13.4\right.$ weeds $\left./ \mathrm{m}^{2}\right)$. The lowest density was noticed at Kg. Teluk Wang Besar (0.4 weeds $/ \mathrm{m}^{2}$ ) and Kg. Banggol (1.2 weeds $/ \mathrm{m}^{2}$ ) (Figure 4).

The highest relative density was in Taman Cahaya Baiduri (23.74\%) followed by Kg. Penghulu Him (22.19\%), Kg. Kongsi 6 (19.85\%), and Kg. Zainal Abidin (19.79\%) (Table 2).

It is not clear to us that why such a variability in parthenium density exists among different villages. Since the people of all these villages were unaware about this invasive species [4], the discrepancy in weed densities might be due to natural selection. More or less similar ranking of weed frequency was noticed in different survey sites. For example, the highest frequency was noted in $\mathrm{Kg}$. Kongsi 6, Kg. Penghulu Him, Kg. Telok, Taman, and Cahaya Baiduri, and 

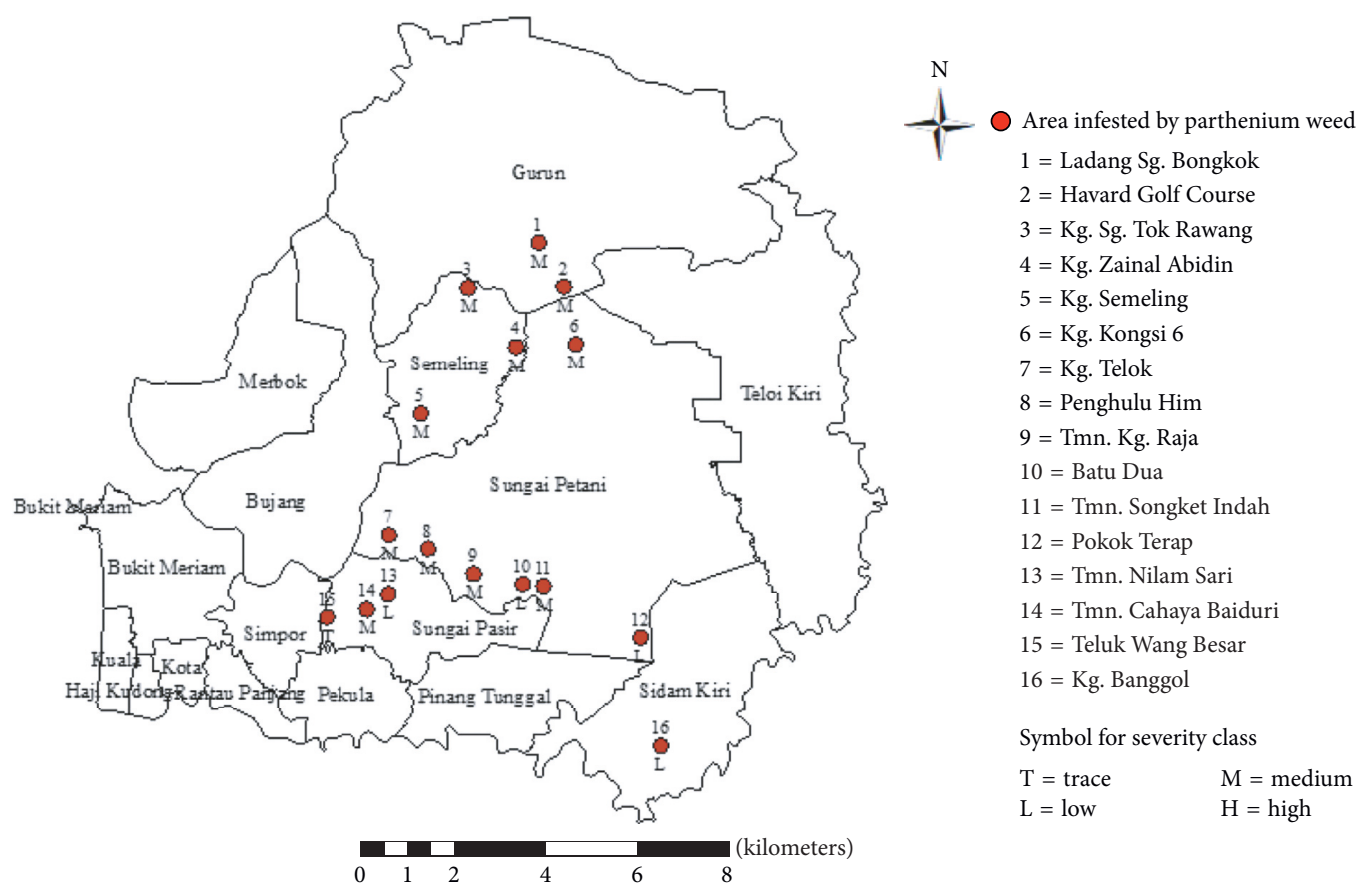

Symbol for severity class

$\mathrm{T}=$ trace $\quad \mathrm{M}=$ medium

$\mathrm{L}=$ low $\quad \mathrm{H}=$ high

(a)
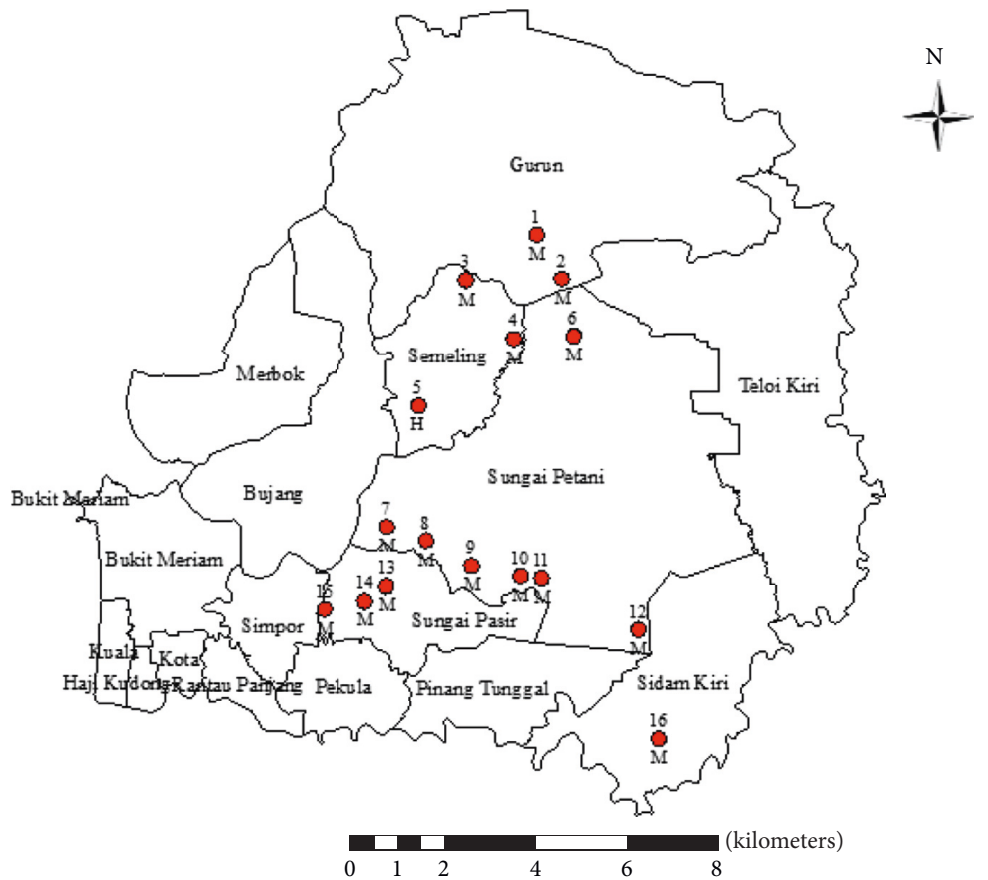

Area infested by parthenium weed

$1=$ Ladang Sg. Bongkok

2 = Havard Golf Course

$3=\mathrm{Kg}$. Sg. Tok Rawang

$4=$ Kg. Zainal Abidin

$5=$ Kg. Semeling

$6=$ Kg. Kongsi 6

$7=$ Kg. Telok

$8=$ Penghulu Him

$9=$ Tmn. Kg. Raja

$10=$ Batu Dua

$11=$ Tmn. Songket Indah

$12=$ Pokok Terap

$13=$ Tmn. Nilam Sari

$14=$ Tmn. Cahaya Baiduri

$15=$ Teluk Wang Besar

$16=\mathrm{Kg}$. Banggol

Symbol for severity class

$\mathrm{T}=$ trace $\quad \mathrm{M}=$ medium

$\mathrm{L}=$ low $\quad \mathrm{H}=$ high

(b)

Figure 2: Map showing parthenium infestation at Kuala Muda, Kedah, in March (a) and September 2015 (b). Note that, in the second survey, the severity of infestation has changed from " $L$ " to " $M$ " in some locations and in one location from " $M$ " to " $H$."

the lowest frequency was in Kg. Banggol, Kg. Teluk Wang Besar, and Pokok Terap (Table 2).

During the second survey in September 2015, a significant change occurred in weed density at Kuala Muda, Kedah. The weed density increased in most of the survey sites, ranging from 2.2 to 24.3 weeds $/ \mathrm{m}^{2}$. The highest density was recorded at Kg. Kongsi 6 (24.3 weeds $\left./ \mathrm{m}^{2}\right)$, Kg. Semeling
(21.2 weeds $/ \mathrm{m}^{2}$ ), and $\mathrm{Kg}$. Zainal Abidin (15.1 weeds $/ \mathrm{m}^{2}$ ), and the lowest was at $\mathrm{Kg}$. Banggol (2.2 weeds $/ \mathrm{m}^{2}$ ) (Figure 5). The average density was higher in the second survey $\left(10.6\right.$ weeds $/ \mathrm{m}^{2}$ ) compared to 8.43 weeds $/ \mathrm{m}^{2}$ in the first survey, although statistically, both were similar (Figure 6). However, there was a little decrease in weed density at four sites, for example, Kg. Penghulu Him, Taman Songket Indah, 


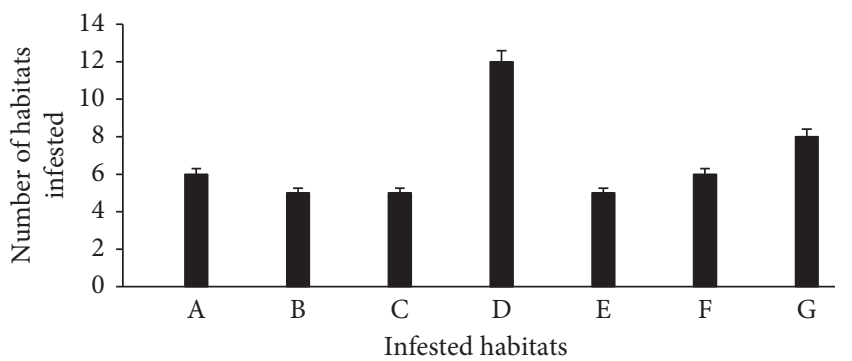

- Kuala Muda

Figure 3: The number of habitats infested with parthenium weed at different sites of Kuala Muda. $\mathrm{A}=$ wasteland, $\mathrm{B}=$ cattle farm area, $\mathrm{C}=$ damping place, $\mathrm{D}=$ roadside, $\mathrm{E}=$ bank of river, $\mathrm{F}=$ farmlands or plantations, and $\mathrm{G}=$ residential area and temples/mosques. Small vertical lines above the bars indicate the standard error of means.

TABLE 2: Total number of quadrats used (NQ), other species/quadrats (OS), number of all species/quadrats (AS), number of quadrats with parthenium (QP), frequency of parthenium distribution (F), parthenium weed abundance (A), relative density (RD) (\%), and symbol for severity class (SC) at Kuala Muda in March and September 2015.

\begin{tabular}{|c|c|c|c|c|c|c|c|c|c|c|c|c|c|c|c|c|c|}
\hline \multirow{2}{*}{ Sites } & NQ & OS & AS & QP & $\mathrm{F}$ & \multirow[t]{2}{*}{ A } & \multirow[t]{2}{*}{$\mathrm{RD}$} & \multirow[t]{2}{*}{ SC } & OS & \multirow[t]{2}{*}{ AS } & QP & $\mathrm{F}$ & A & $\mathrm{RD}$ & SC & \multicolumn{2}{|c|}{$\%$ increase } \\
\hline & & & & Marcl & 2015 & & & & \multicolumn{6}{|c|}{ September 2015} & & A & $\mathrm{RD}$ \\
\hline 1 & 10 & 55.6 & 61.6 & 7 & 0.7 & 8.6 & 9.74 & $\mathrm{M}$ & 41.5 & 53.2 & 7 & 0.7 & 16.7 & 21.99 & $\mathrm{M}$ & 48.50 & 55.71 \\
\hline 2 & 10 & 59.6 & 64.9 & 6 & 0.6 & 8.8 & 8.17 & M & 32.5 & 37.4 & 6 & 0.6 & 8.2 & 13.1 & $\mathrm{M}$ & -7.32 & 37.63 \\
\hline 3 & 10 & 59.9 & 72.6 & 7 & 0.7 & 18.1 & 17.49 & $\mathrm{M}$ & 46.4 & 60 & 8 & 0.8 & 17.0 & 22.67 & M & -6.47 & 22.85 \\
\hline 4 & 10 & 54.3 & 67.7 & 7 & 0.7 & 19.1 & 19.79 & $\mathrm{M}$ & 50.3 & 65.4 & 8 & 0.8 & 18.9 & 23.09 & $\mathrm{M}$ & -1.06 & 14.29 \\
\hline 5 & 10 & 48.2 & 59.4 & 7 & 0.7 & 16.0 & 18.86 & $\mathrm{M}$ & 56.6 & 77.8 & 8 & 0.8 & 26.5 & 27.25 & $\mathrm{H}$ & 39.62 & 30.79 \\
\hline 6 & 10 & 75.9 & 94.7 & 8 & 0.8 & 23.5 & 19.85 & $\mathrm{M}$ & 80.7 & 105.0 & 9 & 0.9 & 27.0 & 23.14 & $\mathrm{M}$ & 12.96 & 14.22 \\
\hline 7 & 10 & 50.2 & 62.5 & 8 & 0.8 & 15.4 & 19.68 & $\mathrm{M}$ & 53.8 & 67.4 & 7 & 0.7 & 19.4 & 20.18 & $\mathrm{M}$ & 20.62 & 2.48 \\
\hline 8 & 10 & 55.4 & 71.2 & 8 & 0.8 & 19.8 & 22.19 & $\mathrm{M}$ & 56.7 & 70.0 & 7 & 0.7 & 19.0 & 19 & $\mathrm{M}$ & -4.21 & -16.79 \\
\hline 9 & 10 & 53.0 & 60.9 & 7 & 0.7 & 11.3 & 12.97 & $\mathrm{M}$ & 55 & 63 & 6 & 0.6 & 13.3 & 12.7 & $\mathrm{M}$ & 15.04 & -2.13 \\
\hline 10 & 10 & 52.0 & 54.6 & 4 & 0.4 & 6.5 & 4.76 & $\mathrm{~L}$ & 44.9 & 47.5 & 4 & 0.4 & 6.5 & 5.47 & $\mathrm{M}$ & 0 & 12.98 \\
\hline 11 & 10 & 64.5 & 72.2 & 5 & 0.5 & 15.4 & 10.66 & $\mathrm{M}$ & 49.7 & 55.4 & 5 & 0.5 & 11.4 & 10.29 & $\mathrm{M}$ & -35.09 & -3.60 \\
\hline 12 & 10 & 65.5 & 67.0 & 3 & 0.3 & 5.0 & 2.24 & $\mathrm{~L}$ & 63 & 67.2 & 4 & 0.4 & 10.5 & 6.25 & $\mathrm{M}$ & 52.38 & 64.16 \\
\hline 13 & 10 & 41.6 & 43.6 & 4 & 0.4 & 5.0 & 4.59 & $\mathrm{~L}$ & 39.8 & 49.8 & 5 & 0.5 & 20.0 & 20.08 & $\mathrm{M}$ & 75.00 & 77.14 \\
\hline 14 & 10 & 51.4 & 67.4 & 8 & 0.8 & 20.0 & 23.74 & $\mathrm{M}$ & 49.2 & 64 & 7 & 0.7 & 21.1 & 23.13 & $\mathrm{M}$ & 5.21 & -2.64 \\
\hline 15 & 10 & 83.1 & 83.5 & 3 & 0.3 & 1.3 & 0.48 & $\mathrm{~T}$ & 51.8 & 56.2 & 5 & 0.5 & 8.8 & 7.83 & $\mathrm{M}$ & 85.23 & 93.87 \\
\hline 16 & 10 & 41.5 & 42.7 & 3 & 0.3 & 4.0 & 2.81 & $\mathrm{~L}$ & 39 & 41.2 & 4 & 0.4 & 5.5 & 5.34 & $\mathrm{M}$ & 27.27 & 47.38 \\
\hline Total & 160 & 911.7 & 1046.5 & 95 & 9.5 & 197.8 & 198.02 & & 810.9 & 980.5 & 100 & 10 & 249.8 & 261.51 & & & \\
\hline
\end{tabular}

Note. Site 1 = Ladang Sg. Bongkok; Site $2=$ Havard Golf Course; Site $3=$ Kg. Sg. Tok Rawang; Site $4=$ Kg. Zainal Abidin; Site $5=$ Kg. Semeling; Site $6=$ Kg. Kongsi 6; Site $7=\mathrm{Kg}$. Telok; Site $8=\mathrm{Kg}$. Penghulu Him; Site $9=\mathrm{Tmn}$. Kg. Raja; Site $10=$ Batu Dua; Site $11=$ Tmn. Songket Indah; Site $12=$ Pokok Terap; Site $13=$ Tmn. Nilam Sari; Site $14=$ Tmn. Cahaya Baiduri; Site $15=$ Teluk Wang Besar; Site $16=$ Kg. Banggol; Kg. = Kampung; Tmn. = Taman; Sg. $=$ Sungai.

Taman Cahaya Baiduri, and Havard Golf Course. Probably this change is due to the greater efforts of monitoring and herbicide spraying by the Department of Agriculture, Kedah.

The relative density was in the similar trend as recorded in both the surveys. The highest relative density was in $\mathrm{Kg}$. Semeling (27.25\%), followed by Kg. Kongsi 6 (23.14\%), Taman Cahaya Baiduri (23.13\%), and Kg. Zainal Abidin (23.09\%). The lowest relative density was in Kg. Banggol $(5.34 \%)$ (Table 2). There was more or less similar weed frequency noticed in the second survey, and the highest was in Kg. Kongsi 6 followed by Kg. Sungai Tok Rawang, Kg. Zainal Abidin, and Kg. Semeling. The lowest weed frequency was in Batu Dua, Pokok Terap, and Kg. Banggol. Higher frequency and density of parthenium weed caused its abundance also higher in both the surveys in Kuala Muda, Kedah. From Table 2, it is obvious that the value of weed abundance increased the most in Teluk Wang Besar $(85.23 \%)$ followed by Taman Nilam Sari (75.0\%) and Pokok
Terap (52.38\%). However, there were decreases in parthenium abundance in some locations, especially in Taman Songket Indah (35.09\% decrease). While an average impact of the weed distribution considered, it is clear that on an average, more than $18.0 \%$ increase in weed abundance and $28.0 \%$ increase in relative density were observed in the second survey. Nkoa et al. [5] stated that the weed abundance is related to weed number (density) or frequency, which might have influenced the abundance positively in this study.

3.2.2. Percent Weed Coverage. A significant difference in percent coverage by parthenium weed was observed in different villages $(P<0.05)$. In the first survey, parthenium weed coverage was higher at Kg. Zainal Abidin (23.5\%), followed by places Kg. Semeling and Taman Cahaya Baiduri (23\%) and was the lowest at Teluk Wang Besar (0.9\%) (Figure 7). 


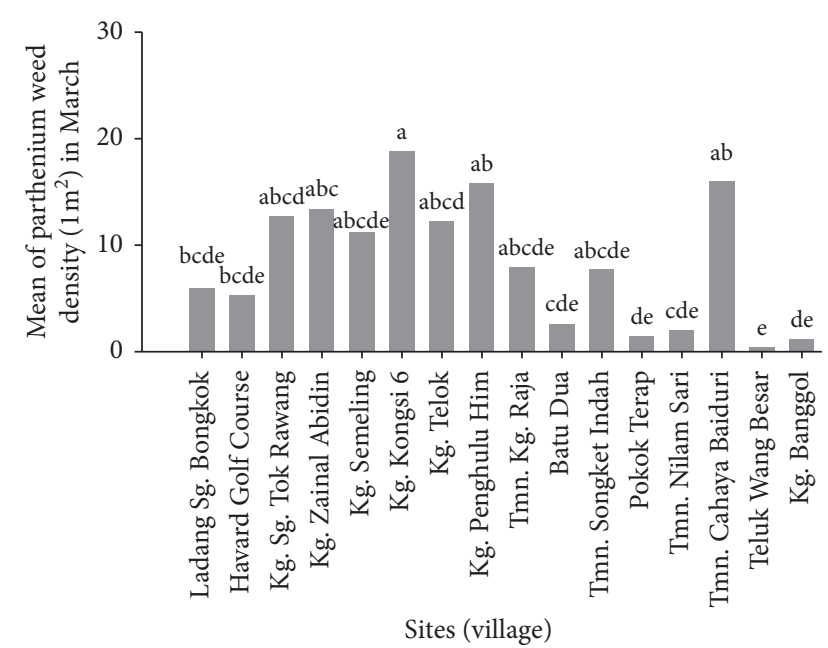

Figure 4: Parthenium weed density of different villages of Kuala Muda in March 2015. Kg. = Kampung, Tmn. = Taman, and Sg. = Sungai. Dissimilar small letters on bars indicate a significant difference.

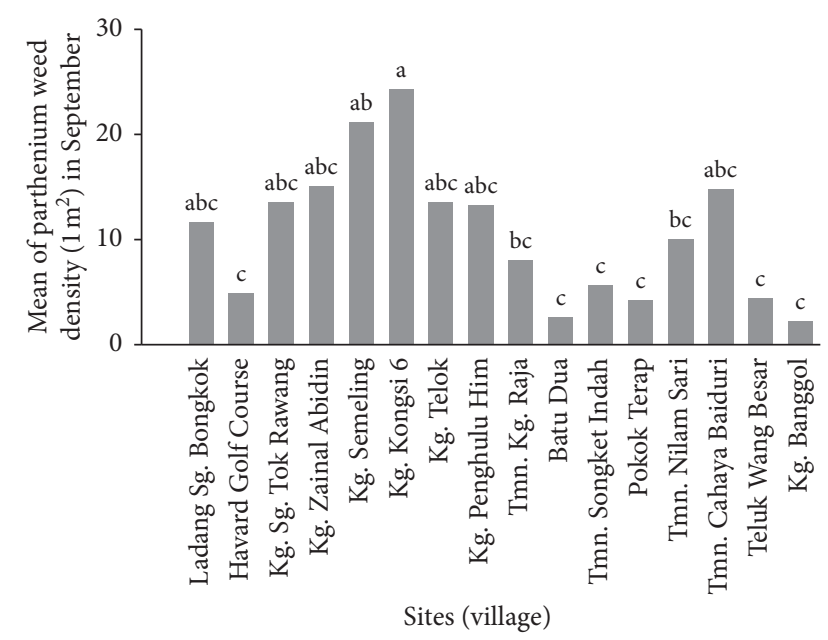

Figure 5: Parthenium weed density at different villages of Kuala Muda, Kedah, in September 2015. Kg. = Kampung, Tmn. = Taman, and Sg. = Sungai. Dissimilar small letters on bars indicate a significant difference.

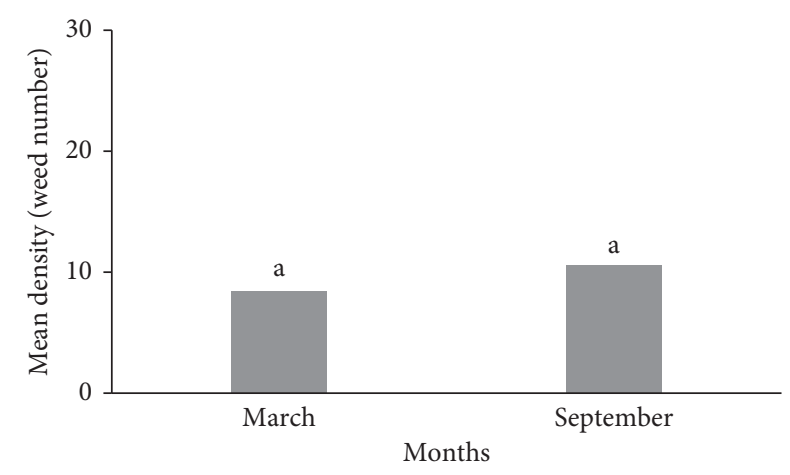

FIGURE 6: Mean density of parthenium weed during two surveys in March and September 2015. The results are the means of all villages. Similar small letters on bars indicate a nonsignificant difference.

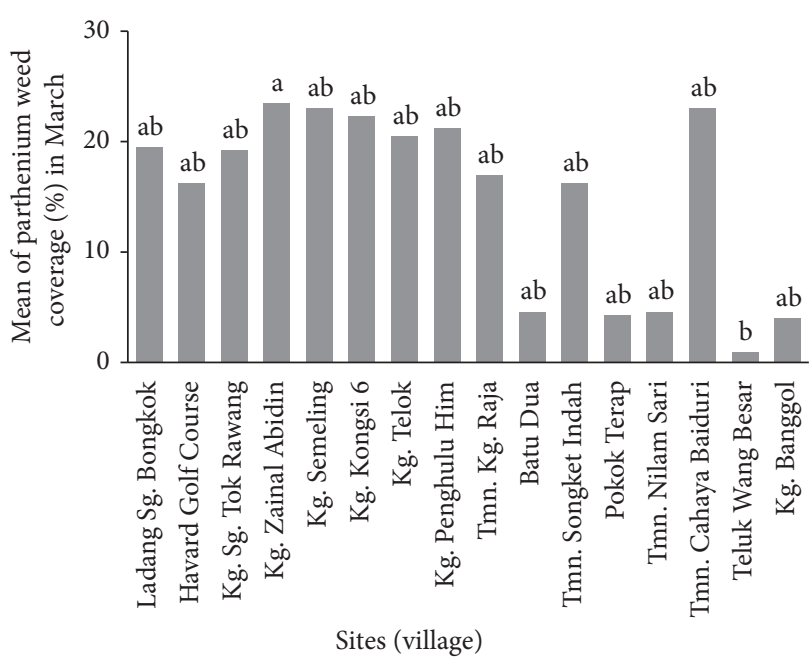

FIgURe 7: Percent coverage by parthenium weed in different villages of Kuala Muda in March 2015. Kg.= Kampung, Tmn.= Taman, and Sg. = Sungai. Dissimilar small letters on bars indicate a significant difference.

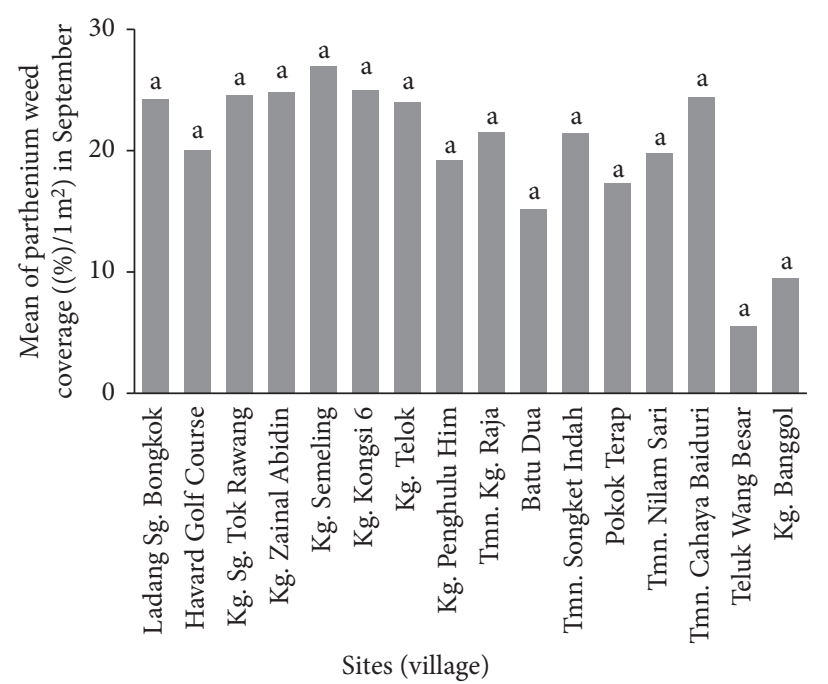

Figure 8: Percent coverage by parthenium weed in different villages of Kuala Muda in September 2015. Kg. $=$ Kampung, Tmn. = Taman, and Sg. = Sungai. Dissimilar small letters on bars indicate a significant difference.

In the second survey, parthenium weed coverage (\%) was higher in Kg. Semeling (27\%), followed by Kg. Kongsi 6 (25\%), and the lowest was at Teluk Wang Besar (5.5\%) (Figure 8).

From the data of percent area coverage, the severity of infestation is regarded as " $\mathrm{M}$ " in most of the sites, except in $\mathrm{Kg}$. Teluk Wang Besar which is regarded as trace (T) and Batu Dua, Pokok Terap, Taman Nilam Sari, and Kg. Banggol are regarded as low (L) infested areas. However, the percent coverage in the second survey increased, and the severity of infestation is regarded as "M" in those sites. However, the severity of the weed is regarded as high ( $\mathrm{H})$ in $\mathrm{Kg}$. Semeling. The overall differences between the two surveys in March and September 2015 were statistically significant $(P<0.05)$ (Figure 9). 


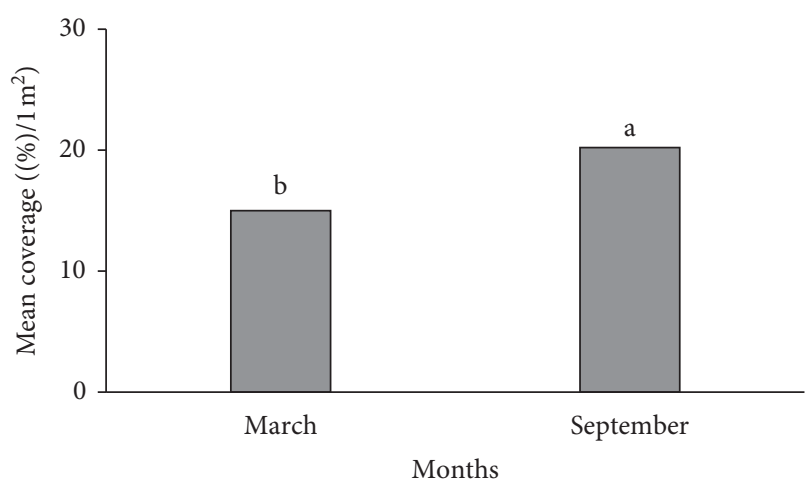

FIGURE 9: The differences of parthenium abundance as measured by weed coverage (\%) for parthenium weed between March and September 2015 at Kuala Muda, Kedah. Dissimilar small letters on bars indicate significant differences.

When the comparison is made between the two surveys, it was obvious that the parthenium weed density was not different. However, the weed abundance as regarded by percent coverage was higher in September than in March 2015 (Figures 6 and 9). Parthenium weed spreads very fast just like wildfire in the forest. Therefore, the increase in weed abundance in Kuala Muda, Kedah, is a matter of great concern to the authority of the country. The control of the weed should follow an integrated approach including prevention, chemical control, physical control, and biological control. The involvement of all stakeholders, for example, researchers, policymakers, administrators, and community people, should be ensured.

\section{Conclusion}

The status of weed density and abundance in Kuala Muda, Kedah, Malaysia, is in a critical stage of infestation and needs quick action to tackle the problem sustainably. Timely control of the weed by adopting appropriate methods especially with an integrated weed management approach is essential.

\section{Data Availability}

Data are available from the corresponding author upon email request.

\section{Conflicts of Interest}

All the authors collaborated in these works are the members of the Parthenium Weed Research Group (PWRG) at theUniversiti Malaysia Kelantan (UMK), Malaysia.

\section{Authors' Contributions}

All the authors contributed to this research in different ways since 2014. S. M. R. Karim designed the study, and C. M. Maszura carried out the field works under the supervision of S. M. R. Karim. M. Z. Norhafizah and C. M. Maszura made the first draft. F. Kayat and M. Arifullah contributed to editing and formatting. The final draft was read and approved by all the authors.

\section{Acknowledgments}

The authors are grateful to the Ministry of Education, Malaysia, for providing the FRGS grant (FRGS/1/2014/ STWN03/UMK/01/1) to carry out this research. The support from the Faculty of Agro-Based Industry, UMK, in conducting the study is acknowledged thankfully.

\section{References}

[1] S. M. R. Karim, Parthenium Invasion in Malaysia: Weed it Out before It's Too Late, Vol. 25, New Strait Times, Kuala Lumpur, Malaysia, October 2013.

[2] S. M. R. Karim, "Malaysia Diserang Rumpai Parthenium hysterophorus yang Paling Serius, Agro Malaysia (Malaysia invaded by the worst weed, Rumpai Miang Mexico, Parthenium hysterophorus)," vol. 12, pp. 40-45, 2014.

[3] S. M. R. Karim, M. Z. Norhafizah, C. M. Maszura, K. Fatimah, and M. Z. Alam, "Perception of local people about Parthenium weed (Rumpai Miang Mexico) in Kedah, Malaysia," International Journal of Biology, Pharmacy, and Allied Sciences, vol. 5, no. 5, pp. 1006-1015, 2016.

[4] DOA (Department of Agriculture), Pengesanan Bancian Rumpai Miang Mexico di Semenanjung Malaysia Sehingga 10 Feb 2015, Jemputan Mesyuarat Jawatankuasa Teknikal Program Kawalan, Pembendungan dan Penghapusan Rumpai Miang Mexico (Parthenium hysterophorus), (Report of the meeting on parthenium weed management in Malaysia) Plant Biosecurity Division, 2015.

[5] R. Nkoa, M. D. K. Owen, and C. J. Swanton, "Weed abundance, distribution, diversity, and community analyses," Weed Science Society of America, BioOne Research Evolved, vol. 63, no. 1, pp. 64-90, 2015.

[6] S. M. R. Karim, "Ill impacts of parthenium weed on human and health and livestock production and environment," in Proceedings of the Invited Seminar by Davies College of Agriculture, West Virginia University, Morgantown, WV, USA, October 2012.

[7] S. Adkins and A. Shabbir, "Biology, ecology and management of the invasive Parthenium weed (Parthenium hysterophorus L.)," Pest Management Science, vol. 70, no. 7, pp. 1023-1102, 2014.

[8] K. V. Sankaran, "Carrot weed (Parthenium hysterophorus)," in Invasive Pest Fact Sheet, APFISN (Asia-acific Forest Invasive Species Network), pp. 1-3, Kerala Forest Research Institute, Peechi, Kerala, India, 2007.

[9] H. Khan, K. B. Marwat, G. Hassan, M. A. Khan, and S. Hashim, "Distribution of Parthenium weed in Peshawar valley, Khyber Pakhtunkhwa-Pakistan," Pakistan Journal of Botany, vol. 46, no. 1, pp. 81-90, 2014.

[10] M. Mahajan and S. Fatima, "Frequency, abundance, and density of plant species by list count quadrat method," International Journal of Multidisciplinary Research, vol. 3, no. 7, pp. 1-8, 2017.

[11] M. Adnan, M. Ali, A. Haider, and A. U. Khan, "Survey of District Sialkot for the infestation of Parthenium hysterophorus," Journal of Biology, Agriculture and Healthcare, vol. 5, no. 1, pp. 111-119, 2015.

[12] M. Tauseef, F. Ihsan, W. Nazir, and J. Farooq, "Weed flora and importance value index (IVI) of the weeds in cotton crop 
fields in the region of Khanewal, Pakistan," Pakistan Journal of Weed Science Research, vol. 18, no. 3, pp. 319-330, 2012.

[13] A. I. Yakubu, J. Alhassan, A. Lado, and S. Sarkindiya, "Comparative weed density studies in irrigated carrot (Daucus carota L.) Potato (Solanum tuberosum L.) and wheat (Triticum aestivum L.) in Sokoto-Rima valley, Sokoto State, Nigeria," Journal of Plant Sciences, vol. 1, no. 1, pp. 14-21, 2006.

[14] J. Knox, D. Jaggi, and M. S. Paul, "Population dynamics of Parthenium hysterophorus (Asteraceae) and its biological suppression through Cassia occidentalis (Caesalpiniaceae)," Turkish Journal of Botany, vol. 35, pp. 111-119, 2011.

[15] R. Kilewa and A. Rashid, "Distribution of invasive weed Parthenium hysterophorus in natural and agro-ecosystems in Arusha Tanzania," International Journal of Science and Research, vol. 3, no. 12, pp. 1-4, 2014.

[16] D. Cooksey and R. Sheley, Montana Noxious Weed Survey and Mapping System, MSU Extension Service MT199613 AG 7, Bozeman, MT, USA, 2002.

[17] Z. Philippoff and E. Cox, Measuring Abundance: Transects and Quadrats, University of Hawaii, Honolulu, HI, USA, 2017.

[18] U. S. Department of Interior, Guidelines for Coordinated Management of Noxious Weeds: Development of Weed Management Areas, National Park Service, and U.S. Forest Service, Bureau of Land Management, Washington, DC, USA, 2001.

[19] M. Worku, "Prevalence and distribution survey of an invasive alien weed (Parthenium hysterophorus L.) in Sheka Zone, Southwestern Ethiopia," African Journal of Agricultural Research, vol. 5, no. 9, pp. 922-927, 2010.

[20] S. M. Masum, M. Hasanuzzaman, and M. H. Ali, "Threats of Parthenium hysterophorus on agroecosystems and its management: a review," International Journal of Agriculture and Crop Science, vol. 6, no. 11, pp. 684-697, 2013.

[21] S. Ayele, L. Nigatu, T. Tana, and S. W. Adkins, "Impact of Parthenium weed (Parthenium hysterophorus L.) on the above-ground and soil seed bank communities of Rangelands in Southeast Ethiopia," International Research Journal of Agricultural Science and Soil Science, vol. 3, no. 7, pp. 262-274, 2013.

[22] S. K. Upadhyay, M. Ahmad, and A. Singh, "Ecological impacts of weed (Parthenium hysterophorus L.) on saline soil," International Journal of Scientific and Research Publications, vol. 3, no. 4, pp. 1-4, 2013. 


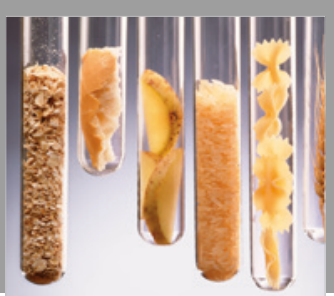

International Journal of Food Science

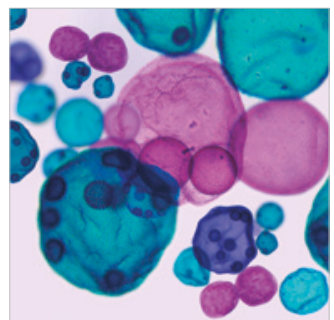

International Journal of Microbiology
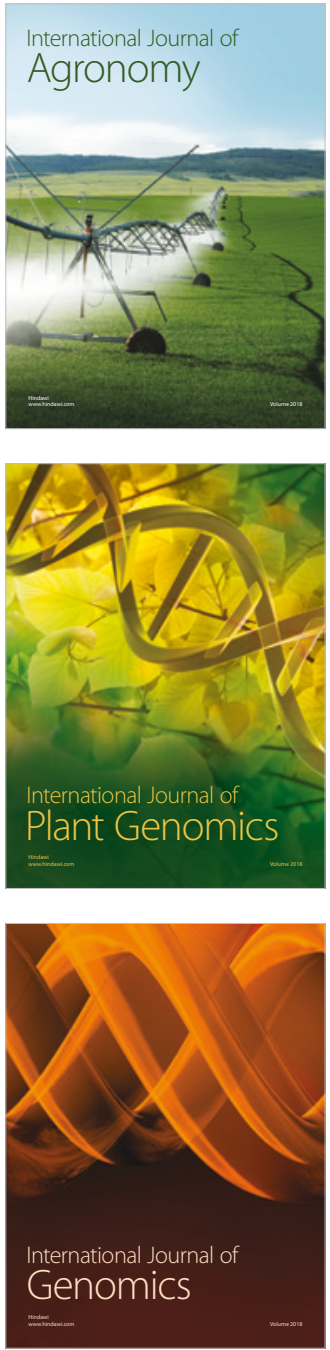

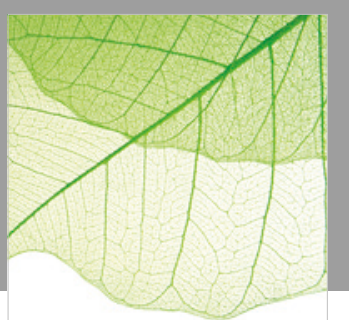

Journal of Botany
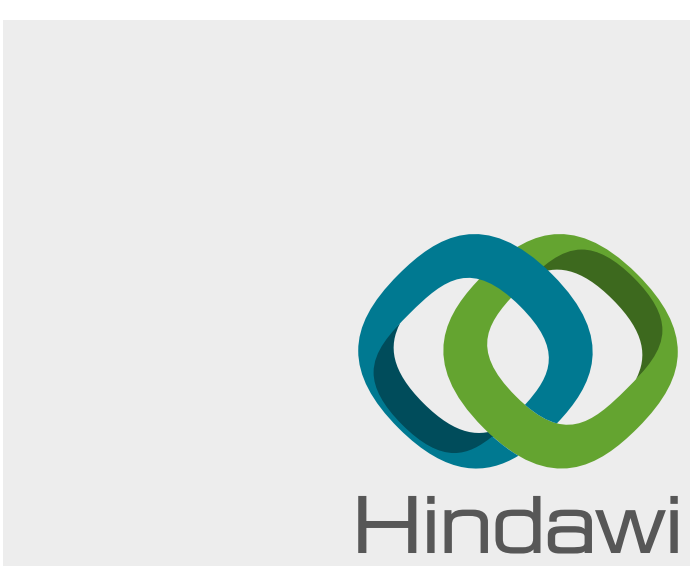

Submit your manuscripts at

www.hindawi.com
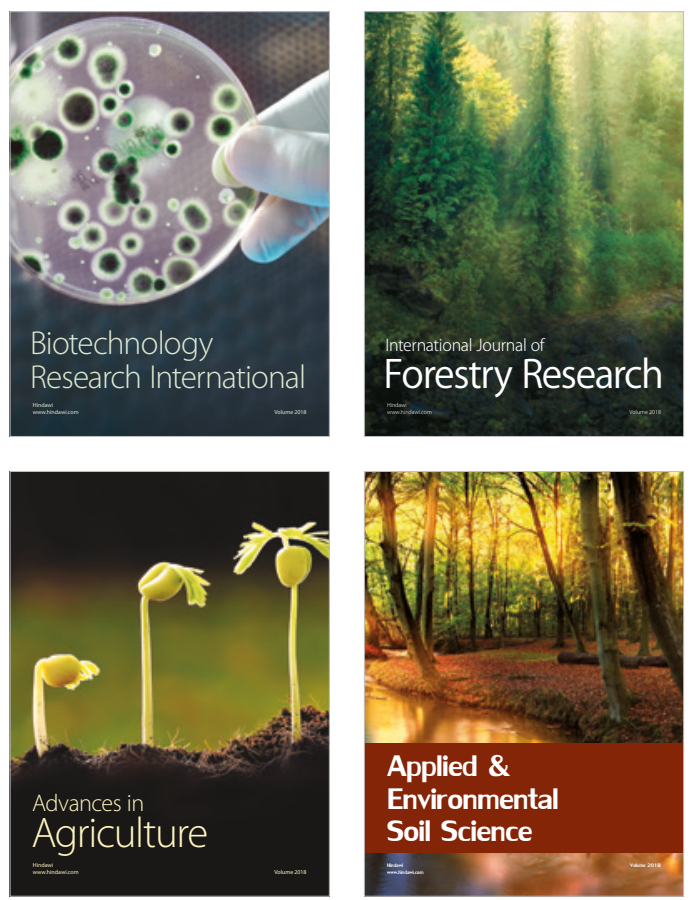

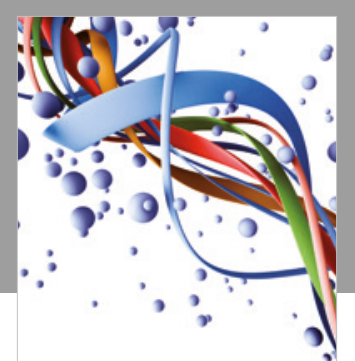

Scientifica

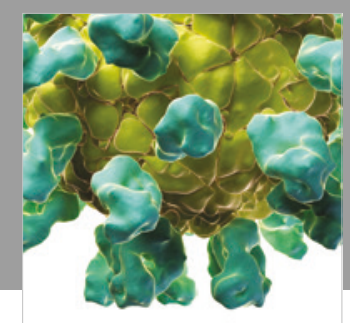

Veterinary Medicine International

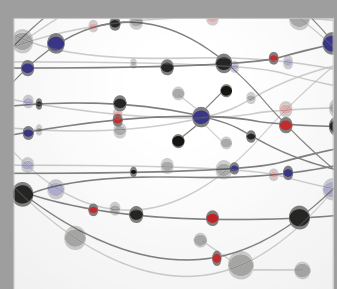

The Scientific World Journal
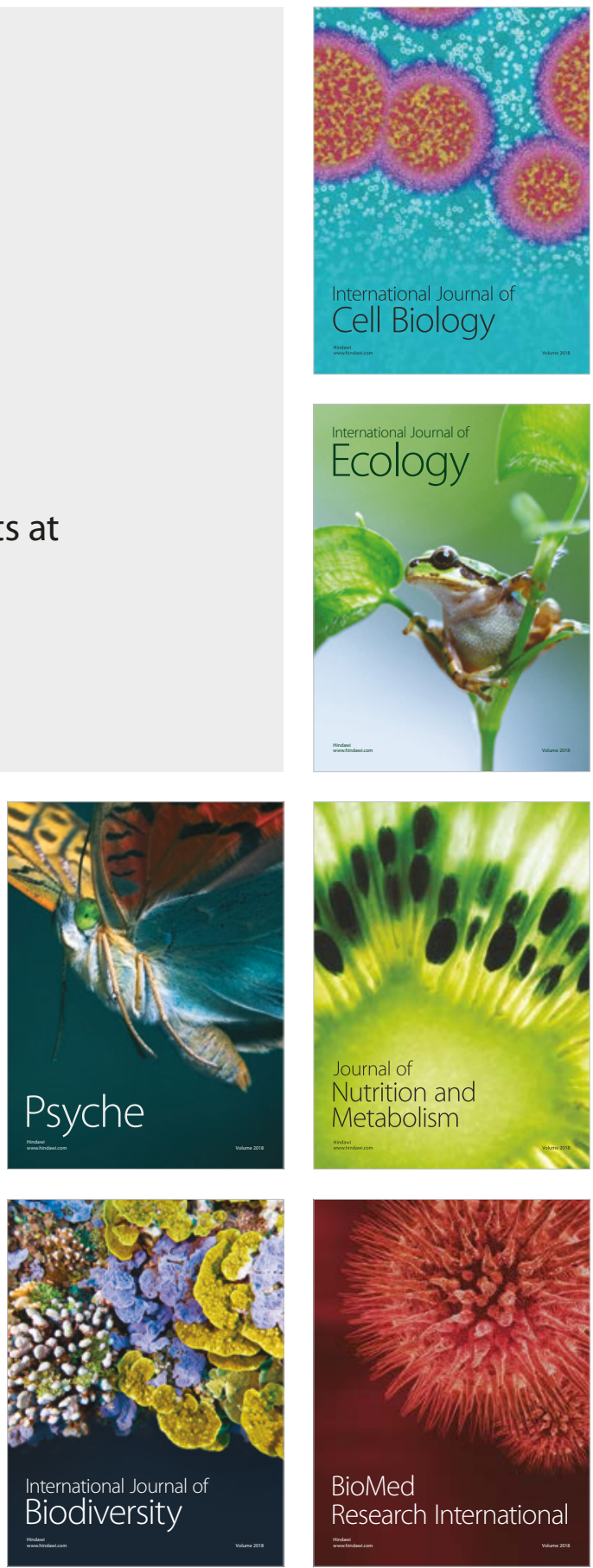